\title{
ANALYSIS OF FACTORS AFFECTING ACCOUNTING STUDENTS IN CAREER SELECTION AS PUBLIC AND NON-PUBLIC ACCOUNTANTS
}

\author{
Adrie Putra \\ Economic and Business Faculty Esa Unggul University \\ Jalan Arjuna Utara No 9 Kebon Jeruk Jakarta 11510 \\ Adrie.putra@esaunggul.ac.id
}

\begin{abstract}
This study aims to find out the factors that influence the career selection of accounting students of Esa Unggul University. In the study the factors measured using financial award variables, professional training, professional recognition, social values, work environment, market considerations and personalities had an influence on the career selection of accounting students as public accountants and non-public accountants. The data collection method in this study was obtained by distributing questionnaires to accounting students of Esa Unggul University and taking samples of 100 respondents. The results of the analysis showed that the variables of financial awards, professional training, professional recognition, social values, work environment, market considerations and personalities had a significant influence on career selection as a public accountant or non-public accountant. This study aims to determine the factors that affect the career choice of Esa Unggul University accounting student. In the study factors were measured using a variable financial reward, professional training, professional recognition, social value, work environment, market considerations and personality has an influence on the selection of the accounting student career as a public accountant or non-public accountant. Methods of data collection in this study were obtained using by distributing questionnaires to Esa Unggul University accounting student and take the sample of 100 respondents. Results of the analysis showed financial variable awards, professional training, professional recognition, social values, work environment, market considerations and personality has a significant influence on the selection of a career as a public accountant or non-public accountant.
\end{abstract}

Keywords: financial awards, professional training, professional recognition, social values, work environment, market considerations and personality.

\section{Introduction}

The selection of a career for an accounting student is the early stages of the career shaper. After successfully completing their studies, career choices for accounting graduates are not covered by the accounting profession alone, many professional options that can be lived by them depending on the factors behind it. Many realities occur in the world of work that require accounting graduates to consider it (Octavian, 2005). Career selection for students is a profession that can be chosen by accounting scholars, there are four types of careers for prospective accounting students, namely public accountants, corporate accountants, accountant educators and government accountants.

Developments in the business world must be responded by the accounting education system in particular in order to produce quality and ready-made graduate accounting in the world of work (Wijayanti, 2001 in Setiyani, 2005). The desire of every accounting graduate in general is to become someone who is professional in the field of accounting especially facing the MEA. The ASEAN Economic Community not only opens up the flow of trade in goods or services, but also the professional labor market, such as doctors, lawyers, accountants, and others. However, a number of professional association leaders admitted to be quite optimistic, that the expert workforce in Indonesia is quite capable of competing. In the field of accounting profession, shows concern because many young workers are not aware of the increasingly tight competition. In addition to their lack of English skills, their readiness also depends heavily on the mentality and competence that they must prepare to compete with foreign accountants. Research motivation is the first, previous research there are many differences about the factors that influence 
career selection for Accounting students in the accountant profession. These differences may occur due to differences in samples taken and also the development of times and changes in existing regulations regarding the accountant profession in addition, there are inconsistent results. Second, career selection for accounting students is very important because it concerns the field of profession a pa that they will live, thirdly to examine accounting students on the factors that distinguish career selection as a public accountant with corporate accountants, government accountants and accountant educators. The factors here are the first or the results obtained as counter achievements that have been fundamentally believed for some companies as the main attraction to provide satisfaction to employees, professional training or matters related to skill-enhancing, professional recognition that includes matters related to achievement, social values that show one's ability in the community, work environment that is the atmosphere of work, consideration of the job market that includes job security and the availability of employment or ease of access to job openings, and lastly personality means psychological characteristics from within a person's individual.

\section{The Foundation of Theory Theory of hope}

Theory Harapan developed by Victor Vroom in 1964 is one of the theories explaining motivation. The theory of hope is the power of a tendency to act in a certain way depending on the strength of an expectation that the action will be followed by the results that exist and on the attractiveness of that outcome towards the individual. Based on this theory, it can be explained that workers will get the encouragement to give maximum effort when they believe that the business will produce a good assessment of their performance, which in the end they will get awards for their good performance. A good performance assessment will encourage organizational rewards such as bonuses, financial/salary increases or promotions.

Maslow's hierarchical theory of needs is a theory expressed by Abraham Maslow who thinks that needs at a low level must be met or at least adequately met first before the needs at the higher level become the motivational thing. Maslow's hierarchy of needs states that in each individual there is a level for 5 (five) needs namely:

1. Physiological Needs

2. Security Needs

3. The need for love, affection and ownership

4. Esteem Needs

5. The Need for Self-Actualization

\section{Types of Accountant Professions in Indonesia Public Accountant profession}

The public accountant profession has its own formal regulations stipulated in Law No. 5/2011 on "Public Accountants" which came into force on May 3, 2011. For the field of services provided by public accountants has been regulated in Article 3 which states that, public accountants provide insurance services that include audit services on historical financial information, review services on historical financial information and other insurance services.

\section{Corporate Accountant Profession}

An accountant (internal) is an accountant who works in a company and is responsible for accounting problems in the company. The scope of the task of the company's accountant is to develop an accounting system that is contested by the company, prepare financial statements for internal and external parties, the company's budget, conduct checks on the implementation of the accounting system and budget and solve tax problems, such as tax calculation. An accountant or internal auditor is an accountant working in an entity or company whose main task is to determine whether the policies and procedures established by the top management have been adhered to, determining whether or not of the organization, determining the efficiency and effectiveness of organizational activities procedures, and determining the reliability of information produced by various parts of the organization (Trirorania, 2004).

\section{Public Accountant Profession}

Public accountants are accountants who work in government institutions and are tasked with controlling, and examining the use of state finances or wealth and making audit results reports. Government accountants generally work in the Ministry of Finance (Directorate 
General of State Financial Supervision), the Audit Board (BPK) and the Financial and Development Supervisory Agency (BPKP).

\section{Accountant Profession Educators}

Accountant educators are accountants who become teaching staff in high school and tasked with developing accounting education. They generally do not teach solely, but also with other jobs, for example by opening practices to meet the needs of the community or those who need their expertise.

\section{Career Student Majoring in Accounting.}

Wijayanti (2001) stated the factors that accounting students consider in choosing a career as a public accountant and non-public accountant include financial awards, professional training, professional recognition, social values, work environment, job market considerations, and personalities. Unlike the research conducted by Kunartinah (2003) which uses factor salary, job market considerations, excess public accountants, weaknesses of public accountants and personalities.

\section{Salary/Financial Income}

Financial income or salary is the result obtained as a counter-achievement of work that has been believed to be fundamental to most companies as the main attraction to provide satisfaction to employees. In the salary factor, usually students will take into account the salary earned at the time of starting work, starting from the guarantee of the future that guarantees the existence of pension funds, in addition to the perception of students also take into account when the salary increase will be obtained (Yendrawati, 2007:179).

\section{Professional training}

Professional training includes matters related to improving skills towards achievement. Professional training and recognition can be categorized as financially intangible rewards. In choosing an accountant profession is not only aimed at seeking financial rewards, but also there is a desire to excel and expand themselves. In this factor usually the perception of students will see if before they work given training as a provision they work or organized by outside institutions where they work. In addition, the perception of students also wants a variety of work experience, so as not to experience saturation in work (Yendrawati, 2007:179).

\section{Social Values}

Social values are shown as factors that show one's ability in their society, and in other words the value of a person from the point of view of others in his environment (Revelation, 2006:179).

\section{Work Environment}

The employee's work environment has no small influence on the company's operational activities. According to Nitisemito in Azlina (2008:19 38) the meaning of the work environment is everything that is around the workers and affects him in completing all the tasks imposed on him by the company.

\section{Job market considerations}

Consideration of the job market isone of the factors that can be used to determine career choices. Job market considerations include job security and ease of access to jobs (Rahayu, 2003:825).

\section{Personalities}

Personality is one of the potential determinants of individual behavior when dealing with certain situations/ conditions. This proves that personality affects a person's behavior. Personality is tested with a statement $\mathrm{n}$ about the suitability of work with the personality of a person (Rahayu, 2003:825).

\section{Previous Research}

Rahayu (2003) conducted research on the perception of accounting students on the factors that influence the career selection of independent accountants Variable used are financial awards, professional training, professional recognition, social values, work environment, job market considerations, and personalities. The results showed that financial awards, professional training, professional recognition, and work environment had a significant influence on the selection of students' careers as public and non-public accountants.

Trironia (2004) examined the factors that influence the selection of the accounting profession by the student accountants\. 
Independent variables used are financial/salary awards, professional recognition, professional training, work environment, social values, and job security. The results showed that financial awards, professional recognition, employ meant have a significant influence on the selection of students' careers as public or non-public accountants.

\section{Research Methods}

Relationships between financial award variables, professional training, professional recognition, environmental social values, job market considerations, and personalities towards the selection of accounting students' careers as public and non-public accountants.

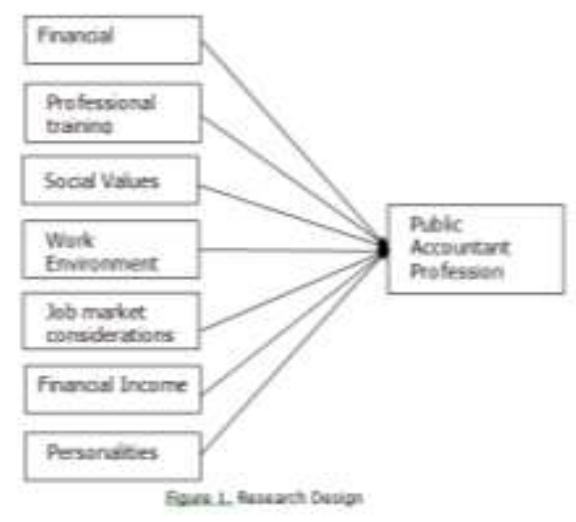

Relationships Between Variables The Effect of Salary or Financial Appreciation on Student Career Selection As Public Accountant and Non-Public Accountant

In Rahayu (2003) showed that students who choose a career as a corporate accountant and government accountant consider with that career their starting salary is high, compared to students who choose a career as a public accountant and accountant educators who consider that the starting salary in their career is not so high. Pension funds are highly expected by students who choose careers as government accountants and accountant educators, while students who choose a career as a corporate accountant are not so expected to earn a pension fund. Students who have $h$ careers as public accountants even less expect a pension fund.

The Effect of Professional Training on Career Selection of Accounting Students as Public Accountants and Non-Public Accountants
In Rahayu (2003) showed that a career as a public accountant is considered more necessary job training to improve the ability of the profession and get a variety of work experience, while in corporate accountants and government accountants consider that job training is less necessary, while for accountant's student educators consider the need for job training, so that work experience varies less obtained than a career as a corporate and government accountant.

\section{The Effect of Professional Recognition on} The Career Voters of Accounting Students as Public Accountants and Non-Public Accountants

In Wijayanti's research (2001) that professional recognition is not

considered by students in choosing a profession because students suppose that this type of the profession they choose must give recognition of the accountant profession, so in this case there is no difference in perception of professional recognition among students who choose the profession of accountant public, corporate accountants, accountant educators, and government accountants.

The Influence of Social Values on The Career Selection of Accounting Students as Public Accountants and Non-Public Accountants

Stolle (1976) in Apriliyan (2011) shows that social values are shown as factors that show a person's ability in his society, or in other words the value of someone from the point of view of others in his environment. His research shows that social value is balanced in choosing a profession. Accounting students consider the public accounting profession to provide more social services and more prestigious than the accounting profession of the company. This means that a person's decision to choose carrier is influenced by other people's view of the work.

Effect of Work Environment on Career Selection of Accounting Students as Public Accountants and Non-Public Accountants

Rahayu (2003) showed that a career as an accountant educator more routine than other careers. Career as an accountant 
government routine works whose routine is slightly higher than that of a corporate accountant. A career as a public accountant is considered a career whose type of job is not routine, more attractive and many challenges, cannot be quickly resolved. The work environment is almost the same as the work environment of accountant educators.

\section{Effect of job market considerations on the career selection of accounting students as public accountants and non-public}

According to Rahayu (2003) students who choose a career as an accountant government and accountant educators consider job security and employment safer. Job security on a career as a public accountant is slightly safer than security very easy corporate accountant in layoffs. Accessing a career as an accountant educator and corporate accountant is easier compared to a career as an accountant educator and government accountant is fun but often overtime and competition between employees are very high and there is pressure to achieve success. Career choice as a government accountant is almost the same as a corporate accountant that is fast work can be completed, not so often overtime, little work pressure, competition between employees a little and less challenges. Career as an accountant educator his job can be completed more quickly and many challenges because he often meets many people

The influence of personality on the selection of accounting students' careers as public accountants and non-public accountants

In Widyasari (2010) there is no difference in the perception of accounting students in career selection reviewed from personalities. The results of different tests on indicator reflect the personality of a person who works professionally shows that there is no difference in perception. In the selection of a career as an accountant the results of Jumamik (2007) stated that personality variables have a significant effect on career selection as an accountant. The results of this study are supported by the results of research conducted by Apriliyan (2011).

\section{Hypothesis}

Based on the above, for the hypothesis as follows:

$\mathrm{H}_{1}$ : Salary / financial delivery, professional training, professional recognition, social values, work environment, market considerations and personalities influence the selection of accounting careers.

$\mathrm{H}_{2}$ : Salary or income affects the selection of students' careers as public accountants and non-public accountants.

$\mathrm{H}_{3}$ : Professional training affects student career selection Accounting as a public accountant and non-public accountant.

$\mathrm{H}_{4}$ : Professional recognition influences the selection of Accounting students' career as a public accountant and non-public accountant.

$\mathrm{H}_{5}$ : Social values affect the career selection of Accounting students as public accountants and non-public accountants.

$\mathrm{H}_{6}$ : The work environment affects the career selection of Accounting students as public accountants and non-public accountants.

H7: Market considerations affect the career selection of Accounting students as public accountants and non-public accountants.

$\mathrm{H}_{8}$ : Personality affects the career selection of Accounting students as public accountants and non-public accountants.

\section{Population, Sample Count and Sampling Techniques}

The population is an entire number of elements that have one or two characteristic or the same characteristics. The population in this study were all students majoring in accounting from the class of 2012 - 2014 who were recorded as still active as students of Esa Unggul University. They are deliberately chosen because they have generally given enough knowledge because they have got a variety of knowledge related to accounting so that it is expected to determine the type of career they will pursue.

Samples are partly or act as representatives of population so that the results of successful research obtained from the 
sample can be generalized in the population. In this study, the determination of sample size using the Slovin:

$$
\mathrm{n} \frac{N}{\exists+N(e) 2}
$$

Where:

$\mathrm{n}=$ Sample size

$\mathrm{N}=$ Population size

$\mathrm{E}=$ Error or error specified, but still tolerable. The assigned error rate is $10 \%$.

Therefore, the sample used if formulated in the formula becomes as follows:

$$
\begin{aligned}
& \mathrm{n}=\frac{N}{1+N(e) 2} \\
& \mathrm{~N} \frac{276}{1+276(0,1) 2} \\
& =99.76 \\
& =100
\end{aligned}
$$

The sample used in this study was as many as 100 people. The questionnaire was distributed to 100 respondents. Sampling techniques in this study Stratified Random Sampling is dividing population in several strata and then taking samples from each group in accordance with the criteria set. In this study the population was divided into two strata 2012 and 2013 with the following calculations:

$2012=\underline{142}$

$$
\begin{aligned}
& 276 \times 100 \\
= & 51.44 \\
2013= & \frac{134}{276 \times 100} \\
= & 48.55
\end{aligned}
$$

While the reason for the choice of student population 2012 - 2013 because they have attended the accounting examination course and for the class of 2014 was not chosen because it does not meet the criteria are:

1. Knowledge of this audit makes people competent to evaluate financial fairness. after taking this course, allows the student is interested further to choose the accounting profession.

2 They already have a plan or thoughts about the career selection that they undergo and persevere after graduating from Esa Unggul university.

\begin{tabular}{|c|c|c|c|c|c|}
\hline & $\mathrm{N}$ & Minimum & Maximum & Mean & Std. Deviation \\
\hline Financial Awards & 100 & 1,00 & 5,00 & 3,2700 & 1,10878 \\
\hline $\begin{array}{c}\text { Professional License } \\
\text { Plate }\end{array}$ & 100 & 2,00 & 5,00 & 3,4400 & 85658 \\
\hline Professional Recognition & 100 & 1,00 & 5,00 & 3,5200 & 89307 \\
\hline Social Values & 100 & 2,00 & 5,00 & 3,5000 & ,90453 \\
\hline Work Environment & 100 & 1,00 & 5,00 & 3,4500 & ,90314 \\
\hline Market Considerations & 100 & 1,00 & 5,00 & 3,5900 & ,94383 \\
\hline Personalities & 100 & 1,00 & 5,00 & 3,3500 & 1,12254 \\
\hline Valid N (listwise) & & & & & \\
\hline
\end{tabular}

\section{Descriptive Statistical Analysis}

Descriptive statistical analysis is used with intent as a way to find out the values of variables in the research that has been done. Below is a table of descriptive statistics that explain the minimum, maximum, mean and standard values of research variable deviation.

Table 1

Descriptive statistics

The table above describes the statistical description of the variables in this study. Minimum is the smallest value in the variable, maximum is the highest value in the variable, mean (average) that is the total sum of the value of all data divided by the amounts of data, the last standard deviation is the root of the sum of squares of the difference in data values with the average divided by the amount of data. 
Jurnal Ekonomi : Journal of Economic p-ISSN: 2087-8133 | e-ISSN: 2528-326X

The data above shows that:

1. financial awards show that an average of 3.2700 this will affect the selection of accounting students' careers as public and non-public accountants, as well as the standard deviation of 1.10878 .

2. Professional training shows that an average of 3.4400 this means agreeing to influence career management as a public and non-public accountant, as well as a standard deviation of 0.85658 .

3. Professional recognition shows that an average of 3.5200 , this means agreeing that affects the career selection of accounting students as public and nonpublic accountants, as well as the standard deviation of 0.89307 .

4. social values show that an average of 3.5000 , this means agreeing that affects the career selection of student's agency as a public and non-public accountant, as well as a standard deviation of 0.9045 .

5. The Work Environment shows that an average of 3,4500 , this means agreeing that affects the career selection of accounting students as public and nonpublic accountants, as well as a standard deviation of 0.90314 .

6. Market considerations show that 3.5900, this means agreeing that affects the career selection of accounting students as public and non-public accountants, the standard deviation of 0.94383 .

7. Person quality shows that an average of 3.3500 , this means agreeing that affects the selection of accounting students' careers as public and non-public accountants, the standard deviation of 1.12254 .

\section{Validity Test}

Validity test serves as a tool to test the accuracy of measuring instruments so as to reveal the concept of events that have been measured.

Table 2

\section{Validity Test Results}

\begin{tabular}{cccc}
\hline No & Correlation & R table & Description \\
\hline \multicolumn{4}{c}{ Financial Salaries/Awards } \\
1 & 0.895 & 0.1654 & Valid \\
2 & 0.898 & 0.1654 & Valid \\
3 & 0.890 & 0.1654 & Valid \\
\hline
\end{tabular}

\begin{tabular}{cccc}
\hline No & Correlation & R table & Description \\
\hline \multicolumn{4}{c}{ Professional training } \\
1 & 0.708 & 0.1654 & Valid \\
2 & 0.737 & 0.1654 & Valid \\
3 & 0.741 & 0.1654 & Valid \\
4 & 0.709 & 0.1654 & Valid \\
\multicolumn{4}{c}{ Professional Recognition } \\
1 & 0.835 & 0.1654 & Valid \\
2 & 0.866 & 0.1654 & Valid \\
3 & 0.883 & 0.1654 & Valid \\
4 & 0.781 & 0.1654 & Valid \\
\multicolumn{4}{c}{ Social Values } \\
1 & 0.663 & 0.1654 & Valid \\
2 & 0.592 & 0.1654 & Valid \\
3 & 0.642 & 0.1654 & Valid \\
4 & 0.826 & 0.1654 & Valid \\
5 & 0.846 & 0.1654 & Valid \\
6 & 0.961 & 0.1654 & Valid \\
\multicolumn{4}{c}{ Work Environment } \\
1 & 0.832 & 0.1654 & Valid \\
2 & 0.911 & 0.1654 & Valid \\
3 & 0.878 & 0.1654 & Valid \\
4 & 0.801 & 0.1654 & Valid \\
5 & 0.770 & 0.1654 & Valid \\
6 & 0.822 & 0.1654 & Valid \\
7 & 0.915 & 0.1654 & Valid \\
& Market Considerations & Valid \\
1 & 0.933 & 0.1654 & Valid \\
2 & 0.924 & 0.1654 & Personalities \\
\multicolumn{4}{c}{} \\
1 & 1.000 & 0.1654 & Valid \\
\hline
\end{tabular}

Source: processed primary data, year 2016

If $r$ calculates $>r$ table then the indicator or question is said to be valid, while if $r$ calculates $<r$ table then the indicator or question is said to be invalid (Ghozali, 2005). Judging from table 4.5 above, it can be seen that none of the indicators assessed fall in explaining a variable.

This can be seen from the correlation value greater than $r$ table at the level of significance of $5 \%$ or 0.05 , i.e. $d f=N-2=100$ $2=98$ or can be found in the value $r$ table 0.1654 . So the career choice indicators of accounting students that exist on the variables used in this study are worth using as a data collector.

\section{Reliability Test}

Reliability test serves as a tool to test the extent of statues measuring instrument so that it can be used twice to measure the same symptoms and the measurement results are 
relatively the same, so it can be known that the measuring instrument is reliable.

Table 3

Reliability Test Results

\begin{tabular}{lc}
\hline Variable & Alpha \\
\hline Financial salary/award & 0.871 \\
Professional Training & 0.697 \\
Professional recognition & 0.862 \\
Social Values & 0.839 \\
Work Environment & 0.930 \\
Market Considerations & 0.840 \\
Personalities & 1.000
\end{tabular}

Source: processed primary data, year 2016

It can be known that the results of the table above show if the whole variable has an alpha coefficient greater than 0.6 so it can be said that the whole concept of variable meter used in this study is variable. Therefore, the items in each of these variable concepts are worth using as a measuring instrument in statistical testing.

Logistic Regression Analysis Data Analysis Method

Inhypo-thesis testing to find out the influence of factors that influence the selection of careers as public accountants and non-public accountants in a multivariate way, namely by using logistics regression analysis. Logistic regression is generally the sameas the analysis diskriminan that is if we test whether the probability of the occurrence of bound variables can be predicted with free variables (Ghozali, 2011). In logistics tests, the variables used are response variables or dummy-shaped bound. The stick logy test modelis usedto see if dichotomy-scale non-free variables $(Y=0$ and $Y=1$ ) are influenced by free variables both categorical and numerical. The general form of logistic regression opportunity model with $k$ variables is formulated as follows:

$$
\pi(x)=\frac{\exp \left(\beta_{0}+\beta_{1} x_{i}+\ldots+\beta_{k} x_{k}\right)}{1+\exp \left(\beta_{0}+\beta_{1} x_{i}+\ldots+\beta_{k} x_{k}\right)}
$$

Where $n(x)$ is the probability of success of an event or case determined by $y=1$. $\beta 1$ is the parameter value.

\section{Model Feasibility Test (Goodness of Fit)}

The function of uji feasibility model is useful to ensure the similarity of prediction result model with estimated result data. A logistic regression model is said to be good when there is no difference between the observation data and the data obtained from the predicted results.

\section{Table 4}

Hosmer and Lemeshow Test

\begin{tabular}{|l|l|l|l|}
\hline Step & Chi-square & Df & Sig. \\
\hline 1 & 10,566 & 8 &, 228 \\
\hline
\end{tabular}

From the table above hosmer and lemeshow test results obtained chi square value 10,556 with a significance of $0.228(>0.05)$, so it can be concluded that the binary logistic regression model used is able to predict its observation value and the zero hypothesis cannot be rejected or the model is said to be fit.

\section{Coefficient of Determination}

In logistics analysis testing, the determinant coefficient is used to determine the percentage of contribution of the influence of free variable variables on bound variables. Therefore, the numbers in the summary model table are used.

\section{Table 5}

Regression Coefficient

\begin{tabular}{|l|l|l|l|}
\hline Step & $\begin{array}{l}-2 \text { Log } \\
\text { likelihood }\end{array}$ & $\begin{array}{l}\text { Cox \& Snell R } \\
\text { Square }\end{array}$ & $\begin{array}{l}\text { Nagelkerke } \\
\text { RSquare }\end{array}$ \\
\hline 1 & $77,869^{\mathrm{a}}$ &, 450 &, 602 \\
\hline
\end{tabular}

Source: processed primary data, year 2016

Based on the test results obtained Nagelkerke R Square is 0.602 , so it can be concluded that the seven variables of financial awards, professional training, professional recognition, social values, work environment, market considerations and personalities influenced the change of career selection variables 60.2 (0.602x100\%). Which means that all variables affect changes by 60.2 and 
others (100-60.2).

\section{Omnibus Test Tests of Coefficients Models}

Test these Omnibus Tests of Model coeffcients to test whether inserting independent variables into the model will add to the predictive capabilities of the regression model logistics. So, test this Omnibus Test of Model Coefficients to find out the relationship of independent variables to one dependent variable together.

\section{Table 6}

\section{Omnibus Test of Model Coefficient}

\begin{tabular}{|rl|l|l|l|}
\hline & & Chi-square & Df & Sig. \\
\hline Step 1 & Step & 59,759 & 7 &, 000 \\
& Block & 59,759 & 7 &, 000 \\
& Model & 59,759 & 7 &, 000 \\
& & & & \\
\hline
\end{tabular}

Source: processed primary data, year 2016

Based on table Omnibus Test of Model Coefficient shows that the significance level is 0.00 and the result is less than $(0.00<0.005)$ so it can be said that together the variables of financial awards, professional training, professional recognition, social values, work environment, market considerations and personalities, then $\mathrm{H} 1$ is accepted.

\section{Wald Test (Partial Test)}

The test is to determine the amount of influence each individual independent variable has on dependent variables. Wald's test in this study aimed to test whether each coefficient of logistic regression was significant. The Wald test is equal to the square of the logistic regression coefficient ratio $B$ and the standard S.E. The results of this test can be seen in the variables in the equation table. Logistic test results in accordance with the table above, then carried out tests to find out the partial influence. To find out the influence of each variable can be known from Wald test (identical to chi square test). If the significance value is less than 0.05 indicates that the variable has a positive effect on career.

1. The influence of financial awards on career selection as a public accountant or nonpublic accountant obtained a $\beta$ of -0.975 with a significance of 0.009 but the negative beta direction which means $\mathrm{Ho}$ was accepted and $\mathrm{Ha} 2$ was rejected.it can be concluded that financial awards have a negative influence on the selection of careers as accountants.

2 The influence of professional training on career selection as a public accountant or non-public accountant obtained a $\beta$ of 1,624 with a significance of 0.001 but the negative beta direction which means $\mathrm{Ho}$ was accepted and $\mathrm{Ha}_{3}$ was rejected.it can be concluded that professional training has a negative influence on career selection as an accountant.

3. The influence of professional recognition on career selection as a public accountant or non-public accountant obtained a $\beta$ of 0.949 with a significance of 0.006 which means $\mathrm{Ho}$ was rejected and $\mathrm{Ha}_{4}$ accepted. concluded that professional recognition has a positive influence on career selection as an accountant.

4. The influence of Social Values on career selection as a public accountant or nonpublic accountant obtained a value of $\beta$ of 0.858 with a significant of 0.016 which means $\mathrm{Ho}$ was rejected and $\mathrm{Ha}_{5}$ accepted.it can be concluded that the recognition of social values has a positive influence on the selection of careers as accountants.

5. The influence of the work environment on career selection as a public accountant or non-public accountant obtained a value of $\beta$ of 0.993 with a significance of 0.007 which means $\mathrm{Ho}$ rejected and $\mathrm{Ha}_{6}$ accepted. it can be concluded that the work environment has a positive influence on career selection as an accountant.

6. The influence of Market Consideration on career selection as a public accountant or non-public accountant obtained a $\beta$ of 0.888 with a significance of 0.017 but the negative beta direction which means Ho was accepted and $\mathrm{Ha}_{7}$ was rejected. So, it can be concluded that market considerations have a negative influence on the selection of careers as accountants.

7. The influence of personality on career selection as a public accountant or nonpublic accountant obtained a value of $\beta$ of 0.887 with a significance of 0.009 which means $\mathrm{Ho}$ was rejected and $\mathrm{Ha}_{8}$ accepted. So, it can be concluded that professional recognition has a positive influence on 
career selection as an accountant.

Table 7

Test wald

\begin{tabular}{|c|c|c|c|c|c|c|c|c|c|}
\hline & \multirow{2}{*}{ B } & \multirow{2}{*}{ S.E. } & \multirow{2}{*}{ Wald } & \multirow{2}{*}{ df } & \multirow{2}{*}{ Sig. } & \multirow{2}{*}{$\operatorname{Exp}(B)$} & \multicolumn{2}{|c|}{$95 \%$ C.I.for $\operatorname{EXP}(\mathrm{B})$} \\
\hline & & & & & & & & Lower & Upper \\
\hline \multirow{8}{*}{ Step $1^{2}$} & Penghargaan Finansial & $-0,975$ & 0,374 & 6,793 & 1 & 0,009 & 0,377 & 0,181 & 0,785 \\
\hline & Pelatihan Profesional & $-1,624$ & 0,5 & 10,534 & 1 & 0,001 & 0,197 & 0,074 & 0,526 \\
\hline & Pengakuan Profesional & 0,949 & 0,343 & 7,639 & 1 & 0,006 & 2,583 & 1,318 & 5,063 \\
\hline & Nilai - Nilai Sosial & 0,858 & 0,356 & 5,818 & 1 & 0,016 & 2,358 & 1,174 & 4,734 \\
\hline & Lingkungan Kerja & 0,993 & 0,366 & 7,35 & 1 & 0,007 & 2,698 & 1,317 & 5,53 \\
\hline & Pertimbangan Pasar & $-0,888$ & 0,373 & 5,663 & 1 & 0,017 & 0,411 & 0,198 & 0,855 \\
\hline & Personalitas & 0,887 & 0,33 & 7,206 & 1 & 0,007 & 2,427 & 1,27 & 4,638 \\
\hline & Constant & $-0,275$ & 2,254 & 0,015 & 1 & 0,903 & 0,76 & & \\
\hline
\end{tabular}

Source: processed primary data, year 2016

\section{Conclusion}

Based on the results of the research Analysis of Factors Affecting the Career Selection of Accounting Students of Esa Unggul University which is divided in the selection of profession public accountant and non-public accountants, it is known that:

1. There is a positive influence on financial/salary awards, professional training, professional recognition, work environment, social values, job market considerations and personalities. Ho's hypothesis test results were rejected andHa1di received, this means there is a significant influence of all variables because all these variables affect the selection of careers as public and nonpublic accountants.

2 There is a negative influence on physical rewards on the career selection of accounting students. Ho was accepted and $\mathrm{Ha}_{2}$ was rejected, meaning that the lower the form of financial income it would affect the career selection of accounting students as public and non-public accountants.

3. There is a negative influence on professional training on the career selection of accounting students. This is accepted and $\mathrm{Ha}_{3}$ is rejected, this means the lower the professional training in working to improve the professional it will influence the selection of the career of accounting student as a public and nonpublic accountant.

4. There is a positive influence on professional recognition of accounting student career selection. Ho was rejected and $\mathrm{Ha}_{4}$ accepted, this means the greater professional recognition in the job it will affect the career selection of accounting students public and non-public accountants

5. There is a positive influence on social values on the career selection of accounting students. Ho is rejected and $\mathrm{Ha} 4$ is accepted, this means that the greater the social values that a person points out from the point of view of others in the surrounding environment it will affect the selection of a student's career as a public and non-public accountant.

6. There is a positive influence on the work environment on the career selection of accounting students. Ho was rejected and $\mathrm{Ha}_{4}$, this means that the level of competition in the work environment will affect the selection of student careers as public and non-public accountants. There is a negative influence on the consideration of the job market on the career selection of accounting students. Ho accepted and $\mathrm{Ha} 2$ rejected, the lower the employment will affect the selection of student careers as public and non-public accountants.

7. There is a positive influence on personalities on the career selection of accounting students. Ho was rejected and $\mathrm{Ha}_{4}$, this means the greater the personality of the job it will affect the selection of student careers as public and non-public accountants.

\section{Research Findings}

Based on the research above professional training is a factor that dominant in 
the selection of accounting student careers as public and non-public accountants seen from the table wald 10534, the lower professional training in working to improve professional it will affect the selection of accounting student careers as public and non-public accountants, judging from the dominant indicator of professional training that is job training before work is not very considered in the selection of careers as public and non-public accountants because they have got in provision in college time.

The advice given for future research is as follows:

1. For future research, respondents should be further expanded, which is not limited to one university but expanded to include a broader area of coverage and consists of students from various universities, so that the level of generalization is better.

2. Future research should add other independent variables that are likely to influence career selection as public and non-public accountants.

\section{References}

Carl R. Philips and John L. Crain. (1996). "Job Dutiesand Responsibilities in Public Accounting: Are Student Expectations Unrealistic?" Journal of Education, Vol 38 Number 9, pp 21-26, MCB Univrsity Press ISSN 0040-0912 Available at (www.google.com)

Eny, Kusriyati. 2008. "Factors Affecting the Interest of Accounting Students in Choosing a Career in Accounting". Thesis of UGM. Fang Yen Ong. 2009. "Analysis of Student Perceptions of Educators

Ghozali, Imam. 2006. Multivariate Analysis Application with SPSS Program. Diponegoro University Publishing Board. $10 /$

Gibson, et.al, 1996, Organization: Behavior, Structure and Process, Volume 2, Erlangga, Jakarta.

Jumamik, 2007, " Accounting Student's Perception of Influencing Factors Accountant Career Selection", Thesis, USM, Semarang.
Lara Absara Aprilyan. 2011. "Factors Affecting Accounting Students in Career Selection to Become Public Accountants". Thesis published. Faculty of Economics Diponegoro Semarang University.

Octavian, Melani. 2005, "Analysis of Factors That Memotivasi Career Selection for Accounting Students. (Survey Study at Widyatama University Bandung)". The thesis. University of Widyatama Pertama, Publishing Section of STIE YKPN, Yogyakarta

Reni Yendrawati. 2007. "Principles of Accounting Students and Students Regarding Factors-factors That Influence Career Selection as Accountants".

Journal. Islamic University of Indonesia Yogyakarta.

Rivai, Veithzal, 2006. Human Resources Management for Companies: From Robbins, Stephen P.,1996. Organizational Behavior. Volumes 1 and 2. Prehallindo. Jakarta, Jakarta.

Sari Maya. 2013. " Factors Influencing Career Selection to Become a Public Accountant by Students of the Accounting Department of the Faculty of Economics UMSU Medan". Journal of accounting and business research. Vol.13 No.2.

Setiyani, Rediana. 2005. "Factor-F actor Who Distinguishes Accounting Students in Choosing Profession as Public Accountant and Non-Public Accountant. (Empirical Study on Accounting Students of State Universities in Java Island)". Thesis of UNDIP Master of Science Study Program.

Simamora, Henry, 2004. Human Resource Management, Third Edition, Print Theory to Practice, First Edition, Publisher PT. King Grafindo Persada, Jakarta.

Wicaksono, E., 2011, Perception of Accounting Students Regarding Factors That Distinguish the Career Selection of Accountant Profession. Thesis, 
Semarang: Bachelor Program of Faculty of Economics, Diponegoro University.

Widyastuti, et al. 2004. The Influence of Motivation on Mahasiswa Accounting Interest to Follow Accounting Profession Education (PPAk). Sna. December 2-3. Hal 320-339.

Wijayanti. (2001). Factors Influencing the Career Selection of Accounting Students in Yogyakarta. Indonesian Journal of Accounting Research, Vol.3, No.2

Yuanita Widyasari. 2010. "Accounting Student's Perception of The Factors That Distinguish Career Selection". Thesis published. Faculty of Economics, Diponegoro University Semarang.

Yulia Trirorania, 2004, "Factors That Influence the Selection ofProfessions I ntan by Accounting Students", Thesis, UPN, Yogyakarta. 